\title{
Doping in Italy: An Analysis of its Spread in Ten Years
}

Filomena Mazzeo ${ }^{1}$, Marcellino Monda ${ }^{3}$, Giovanni Messina ${ }^{3}$, Stefania Santamaria ${ }^{2}$, Antonietta Messina ${ }^{3}$, Maura Montesano ${ }^{1}$, Vincenzo Monda $^{3}$ and Domenico Tafuri $^{2}$

${ }^{1}$ Department of Science and Technologies, Parthenope University of Naples, Naples, Italy

${ }^{2}$ Department of Sport Sciences and Wellness, Parthenope University of Naples, Naples, Italy

${ }^{3}$ Department of Experimental Medicine, Second University of Naples, Naples, Italy

*Corresponding author: Marcellino Monda, Dipartimento di Medicina Sperimentale, Seconda Università degli Studi di Napoli, via S.M. di Costantinopoli, 16, I-80138 Napoli, Italy, Tel: 390815665804; E-mail: marcellino.monda@unina2.it

Received date: November 19, 2015; Accepted date: December 28, 2015; Published date: January 4, 2016

Copyright: ( 2016 Monda M, et al. This is an open-access article distributed under the terms of the Creative Commons Attribution License, which permits unrestricted use, distribution and reproduction in any medium, provided the original author and source are credited.

\begin{abstract}
Aim: Doping affects the sport. Its explosive spread has triggered the response of sports' and government's institutions. The aims of this study were to know the spread of doping in Italy, what were the most used substances and/or method and in which sports it was more common. Moreover, what instruments were used to contrast it.

Methods: We have analysed the doping's spread in Italy since 2003. The data come from the databases of government and sports Italians institutions. We have compared those data and focused our attention on substances and/or methods discovered in athletes. Furthermore, data's combination showed the reason of drug addiction.

Results: In Italy, only $3 \%$ of checked athletes are doped, many of them are men and young athletes dope less than the older ones. Doped athletes play mainly cycling, athletics, swimming and football. The prominent peak of them is in the Central and Southern Italy in 2008 and 2010. Moreover, the analysis of data relating to galenic preparations declared during the year 2012, shows that $75 \%$ of the prescribed substances are diuretics and masking agents, anabolic steroids and stimulant. Regarding the substances, cannabinoids and stimulants have recorded the highest consumption.

Conclusion: The data show only the tip of the iceberg due to doping's secrecy. Every substance that give pleasant sensations or help the subject in his activity will bring him to repeat the consumption. Frequently, new substances and methods are discovered. For this reason, to contrast this phenomenon, there are legislation instruments together with various funded projects.
\end{abstract}

Keywords: Anti-doping controls; Drugs; Illicit substances; Antidoping legislation

\section{Introduction}

The man has always tried to improve his physical performance by any method: legal or illegal, healthy or harmful to health [1-4].

Doping is an ancient phenomenon. Indeed, the Greek wrestlers and the Roman gladiators attempted to improve their own performance by taking mixtures of various types of plants or by eating sheep's testicles $[5,6]$. Moreover, it is a complex phenomenon analysing the vast variety of substances, supplied through both legal and illegal trading routes and the extensive connections between the people involved in the network [7-9].

Unfortunately, in the past and for a long time, doping was underestimated and public institutions considered it as a problem exclusively of sports organizations that alone had to vanquish a phenomenon in continuous expansion [10-12].
Furthermore, it involves not only elite athletes but amateurs too, their friends and relatives, the medical staff, managers, chemists, biologists and pharmacists, pharmaceutical industries, clandestine laboratories and criminal organizations [13-15]. Some banned substances are available on internet and consumers are not only athletes, but "ordinary" people who buy drugs only for recreational or aesthetic purposes [16-18]. Thus, doping is increasingly a matter that concerns the whole society [1,19-21].

The combination of sport and doping arouses negative reactions. An athlete who takes drugs to win is guilty of fraud and all the stakeholdersimmediately dissociate them from a sport not fair: the sponsors, for example, rescind their endorsements [22-24].

Moreover, the forces that conspire behind doping identify new substances and new methods as well as they steal the new scientific discoveries aimed at the treatment of diseases, for their illegal purposes (Council of Europe, 1989). Botre distinguishes three main periods about the evolution of substances to identify (Table 1) [25].

The first one -the early age- includes "in competition drugs" and the tests were based on gas chromatography; the second period - the androgenic anabolic steroids age - includes "in and out competition 
Page 2 of 9

drugs" and the test were based on gas chromatography/massspectrometry and on liquid -chromatography- mass- spectrometry. The third age - protein chemistry and molecular biology age- includes the newly discovered in genetic engineering used for the treatment of diseases too. This last period includes the blood doping. Indeed, the blood transfusion and administration can boost the capacity to transport the oxygen to the muscles. Now, in the "gene doping age", the new frontier of doping is the use of cells, genes, genetic elements, or the modulation of gene expression with the aim to increase the performance and not easy to detect [25-27].

\begin{tabular}{|c|c|c|}
\hline Period & Years & Substances to identify \\
\hline Early Age & 1970 & Stimulants, narcotics, drugs of abuse \\
\hline $\begin{array}{l}\text { Androgenic Anabolic } \\
\text { Steroid Age }\end{array}$ & $\begin{array}{l}\text { Mid } 1970- \\
2000\end{array}$ & $\begin{array}{l}\text { Synthetic anabolic androgenic steroids, } \\
\text { beta-blockers, diuretic, cannabinoids, } \\
\text { glucocorticoids, human chorionic } \\
\text { gonadotropin, endogenous testosterone } \\
\text { and/or precursor, erythropoietin and } \\
\text { analogs }\end{array}$ \\
\hline \multirow{3}{*}{$\begin{array}{l}\text { Protein Chemistry } \\
\text { and } \quad \text { Molecular } \\
\text { biology Age }\end{array}$} & $2000-2005$ & $\begin{array}{l}\text { Designer steroids, hormone and hormone } \\
\text { receptors modulators }\end{array}$ \\
\hline & 2003-2008 & Blood doping \\
\hline & $2005-2008$ & Peptide hormones \\
\hline Gene Doping Age & $\begin{array}{l}\text { 2008- } \\
\text { present }\end{array}$ & $\begin{array}{l}\text { No substances but cells, genes, genetics } \\
\text { elements, modulation of gene expression }\end{array}$ \\
\hline
\end{tabular}

Table 1: Evolution of substances to identify.

The explosive spread of doping has triggered the response of the International Olympic Committee in 1960 [25,28]. After eight years, during the Olympic Games of Mexico City, there was a pilot project with the aim to analyze the efficacy of anti-doping tests and thanks to their success, the first official anti-doping screening started in 1972 during the Summer Olympic Games of Munich [25]. At beginning, the tests were sporadic and not completely reliable. But in 1999, thanks to the creation of the World Anti-Doping Agency, it finally created an organization with the sole purpose to fight this "cancer" of sport and consequently the situation of tests is changed $[29,30]$. The Agency has compiled a list of banned substances and practices that is constantly updated. Now, WADA, for example, has identified more than two hundred banned substances currently divided into 10 classes (including the class S0) and three methods [31-33].

In 2000 Italy has issued the Law no. 376 that is a concrete response to the fight against doping. Thanks to it, the Italian State aligned itself to the most European and extra European countries engaged in the same direction. The law establishes the National Committee for the supervision and control of doping and for the protection of health in sports. Experts of various fields (medical, legal, political, sports) compose this Commission, which is established within the Ministry of Health. It suggests the classes of drugs, determines cases, criteria and methods of doping controls and identifies the competitions for the tests. In addition, it prepares research programs on drugs, identifies forms of cooperation with the National Health Service for this purpose, maintains work relationships with international entities, and promotes information campaigns and prevention of doping. Moreover, the Commission concludes agreements with the Anti-doping laboratories accredited by the IOC or not accredited by the IOC AntiDoping Laboratory and coordinated by the Regions.

Currently, following a reorganization of the governing entities, the Commission has become Section for the supervision and control of doping and for the protection of health in sport within the newly established Sanitary Technical Committee.

\section{Materials and Methods}

The data show the anti-doping test took place in Italy during the last ten years: from 2003 to 2013. The literature search was performed on PubMed and Scopus database and Italy Anti-doping official website. Data showed are originated from the report commissioned by the Italian Ministry of Health. Indeed, every year -since 2003- anti-doping tests carry out. Perhaps it is possible to know the spread year per year of doping in Italy. The authors have compared the above mentioned data in order to show doping's spread in this last ten years. Tables and diagrams support the comparison.

\section{Results}

First of all, it is important to know that the prohibited substances and/or the amount of substance prohibited constantly change: some of them have been eliminated over time while others have been added. For example, pseudoephedrine and norephedrine were removed from the list in 2003 but in 2013, the first substance was reintroduced with a different dosage. Local anesthetics and caffeine were eliminated in 2004 [31,34], even if the substance has been included in the monitoring program of WADA in 2015 [35].

Since 2003, the Commission carried out doping tests. The tests collected only urine samples.

15.396 athletes have been checked in the last 10 years - 2003 to 2013 -: 10.347 (67.2\%) men and 5.049 (32.8\%) women.

In 2010, the percentage of doped athletes is higher than other years with $4.8 \%$ (53 doped athletes on 1115 controlled) (Figure 1) and from 2008 to 2012 did not fall below $3 \%$. In 2013, the percentage is $2.8 \%$.

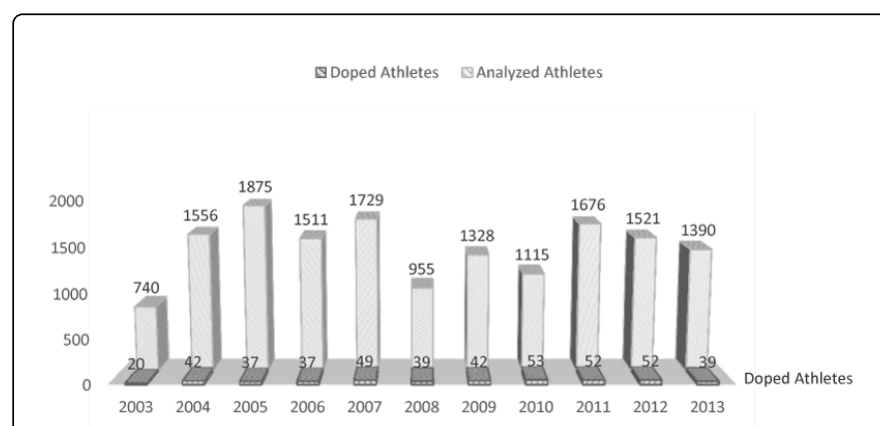

Figure 1: Relation between analyzed and doped athletes expressed in absolute values. Breakdown per year. Reference period: 2003-2013. 
Citation: Mazzeo F, Monda M, Messina G, Santamaria S, Messina A, et al. (2016) Doping in Italy: An Analysis of its Spread in Ten Years. Biol

Page 3 of 9

The total number of doped is 462 corresponding to $3 \%$ of the total analysed, of which 394 men $(85.3 \%)$ and 68 women (14.7\%). The highest percentage of them is recorded for men in 2010 with $6.3 \%$ and for women in 2003 with $2.4 \%$ (Figure 2).

The highest average age of those athletes is 36 in 2010, followed by 35 in 2010. In 2013, the average age is 33 years old and analyzing that average during the last ten years, it is 31 years old.

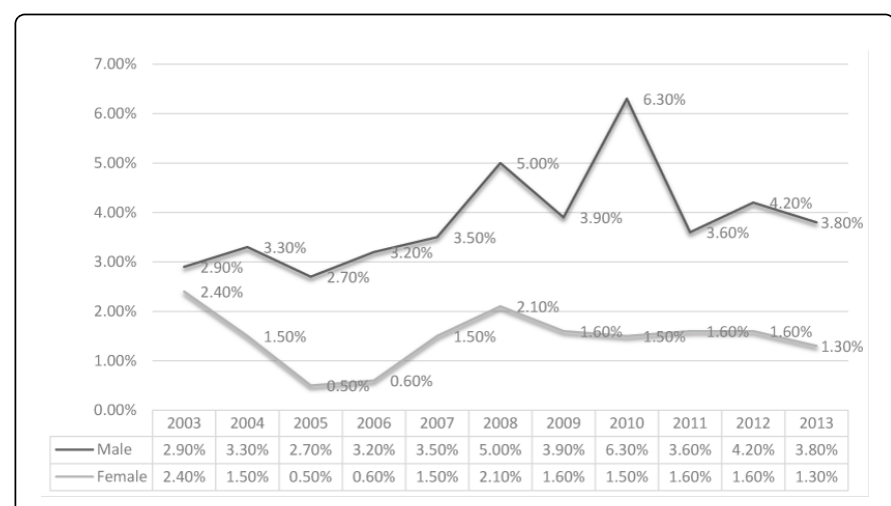

Figure 2: Percentage of doped athletes over the years. Breakdown per gender. Reference period: 2003-2013.

Furthermore, as you can see in the Table 2, the phenomenon mainly touches people over 44 years old and saves younger.

\begin{tabular}{|l|l|l|l|l|l|l|l|}
\hline & $<\mathbf{1 9}$ & $\mathbf{1 9 - 2 4}$ & $\mathbf{2 4 - 2 9}$ & $\mathbf{2 9 - 3 4}$ & $\mathbf{3 4 - 3 9}$ & $\mathbf{3 9 - 4 4}$ & $\mathbf{>} \mathbf{4 4}$ \\
\hline $\mathbf{2 0 0 3}$ & $2 \%$ & $1.10 \%$ & $3.20 \%$ & $4.60 \%$ & $2.40 \%$ & $5.30 \%$ & $10 \%$ \\
\hline $\mathbf{2 0 0 4}$ & $2.40 \%$ & $3.30 \%$ & $0.60 \%$ & $2.70 \%$ & $6.50 \%$ & $3.90 \%$ & $5.10 \%$ \\
\hline $\mathbf{2 0 0 5}$ & $1 \%$ & $1.80 \%$ & 1.8 & $2.70 \%$ & $1 \%$ & $5.90 \%$ & $7.80 \%$ \\
\hline $\mathbf{2 0 0 6}$ & $1.30 \%$ & $2.30 \%$ & $2.30 \%$ & $3.20 \%$ & $3.90 \%$ & $3.10 \%$ & $4.90 \%$ \\
\hline $\mathbf{2 0 0 7}$ & $1.90 \%$ & $3.20 \%$ & $2.20 \%$ & $3.10 \%$ & $3.60 \%$ & $2.50 \%$ & $5.40 \%$ \\
\hline $\mathbf{2 0 0 8}$ & $0 \%$ & $3.10 \%$ & $3.30 \%$ & $6.80 \%$ & $5.70 \%$ & $8.20 \%$ & $13.20 \%$ \\
\hline $\mathbf{2 0 0 9}$ & $0.90 \%$ & $3.70 \%$ & $2.50 \%$ & $4.30 \%$ & $3 \%$ & $2.70 \%$ & $5.20 \%$ \\
\hline $\mathbf{2 0 1 0}$ & $0.40 \%$ & $2.10 \%$ & $5 \%$ & $6.90 \%$ & $8 \%$ & $6.70 \%$ & $7.10 \%$ \\
\hline $\mathbf{2 0 1 1}$ & $1.20 \%$ & $1.10 \%$ & $4.80 \%$ & $2.10 \%$ & $3.20 \%$ & $3.90 \%$ & $7.70 \%$ \\
\hline $\mathbf{2 0 1 2}$ & $0.50 \%$ & $3.60 \%$ & $3.80 \%$ & $5.60 \%$ & $1.90 \%$ & $2 \%$ & $5.60 \%$ \\
\hline $\mathbf{2 0 1 3}$ & $0.70 \%$ & 2.4 & 2.6 & 4.2 & 0.9 & 5.3 & $8.10 \%$ \\
\hline
\end{tabular}

Table 2: Percentage of doped athletes over the years. Breakdown per age groups. Reference period: 2003-2013.

With regards to the geographical distribution, the prominent peak of doped athletes is in the Central and Southern Italy in 2008 and 2010. Indeed, in 2008, the Centre has $8.2 \%$ of those athletes and in 2010 the South and the islands have $9 \%$ (Figure 3).
In particular, the average percentage during the reference period in the three different regions of Italy is following: $2.5 \%$ in the North, $3.5 \%$ in Central and 3.6\% in the South and Islands.

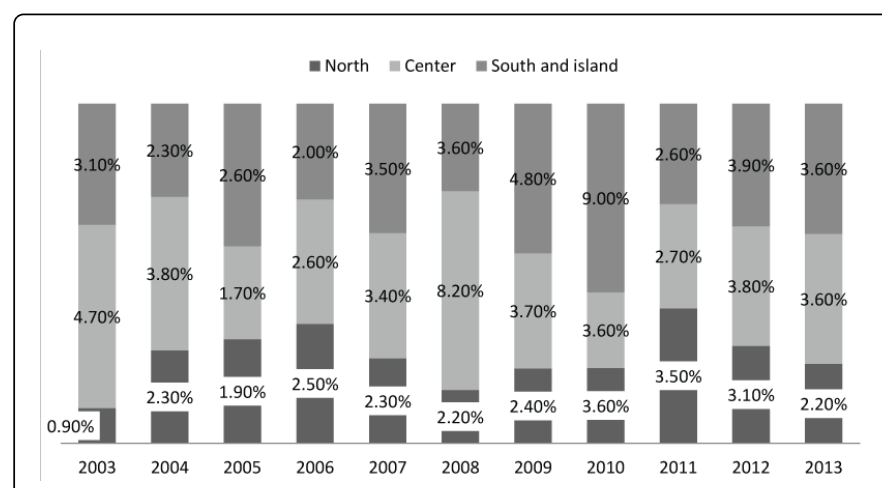

Figure 3: Percentage of doped athletes over the years. Breakdown per areas of Italy. Reference period: 2003-2013.

Shifting the focus on the consumption of prohibited substances (Figure 4) and considered that the control activities of the Anti-Doping Commission began in April 2003, in that year there was a high consumption of stimulants equal to $40 \%$. The lowest percentages are $10.3 \%$ in 2010 and $6.7 \%$ in 2013. Compared with the year 2012, consumption fall by 13 percentage points. The average consumption from 2003 to 2013 is $20.9 \%$.

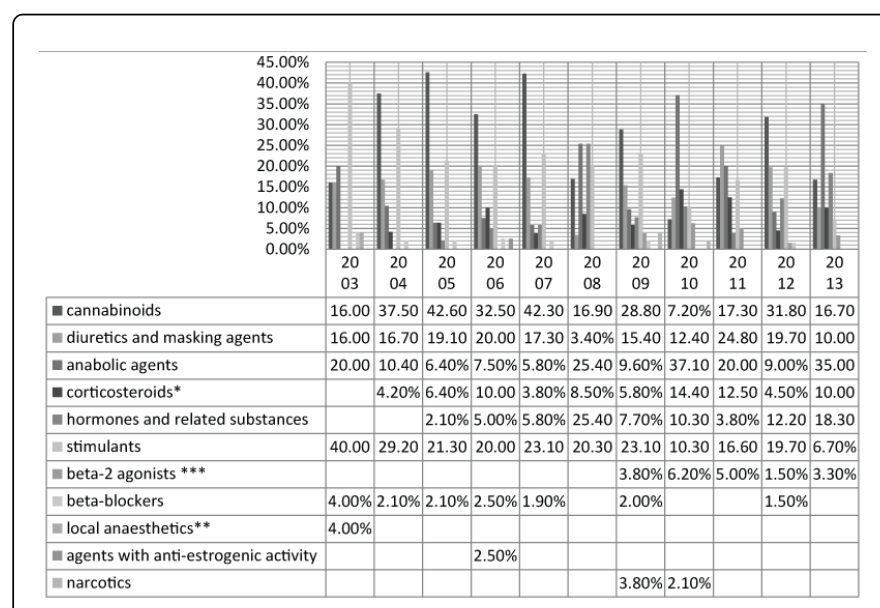

Figure 4: Consumption of prohibited substances over the years. Breakdown per classes of substances and for years. Values are expressed in percentages . Reference period: 2003-2013.

\section{${ }^{\star}$ recognized only since 2004 \\ ${ }^{*}$ not prohibited after 2003 \\ *** recognized from 2009}

The cannabis derivatives have a peak of consumption in 2005 and 2007, respectively, with $42.6 \%$ and $42.3 \%$. Their use in the other years is characterized by ups and downs: it should be noted, indeed, that in 2012 the percentage is $31.8 \%$, while in 2013 is $16.7 \%$. The lowest consumption occurred in 2010 with the $7.2 \%$. The average consumption is $26.3 \%$. 
Page 4 of 9

Regarding diuretics and masking agents, they have almost a constant trend over the years. The peak is reached in 2011 with $24.8 \%$ and 2013 is not recorded specific changes compared to the normal course (10\%). The average consumption of this type of substances is $15.8 \%$.

Anabolic agents experienced a sharp increase in their consumption in 2008 and 2013, respectively with $37.1 \%$ and $35 \%$. The average consumption is $16.9 \%$.

Corticosteroids have a peak in 2010 with $14.40 \%$. The average consumption is $8 \%$. Hormones and related substances have a spike in consumption in 2008 to $25.4 \%$. The trend in consumption was fluctuating and the average is $20.3 \%$.

Beta-2 agonists have been banned since 2009. Their peak occurred in 2010 with the $6.2 \%$ of consumption and, after a brief decline in 2012 by $1.5 \%$. Its average consumption is $3.9 \%$.

Beta-blockers are irrelevant over the years. There are no data for 2013 and its average fuel consumption is $2.3 \%$.

Another exception should be made for local anaesthetics as they were prohibited only in 2003. Regarding agents with anti-estrogenic activity the only data currently available date back to 2006 and the same discussion can be done for narcotics for which there are data only for the years 2009 and 2010, respectively, with a consumption of $3.8 \%$ and $2.1 \%$, with an average of $2.9 \%$.
In 2013 on 1390 doping tests, 179 urine samples were analysed for the research of erythropoietin and similar. The tests showed that $9.5 \%$ of them took one or more banned substances. $82.3 \%$ of them took one or two substances prohibited while $17.7 \%$ three or more substances.

Moreover, the analysis of data relating to galenic preparations declared by pharmacists during the year 2012 , shows that $75 \%$ of the prescribed substances are diuretics and masking agents, anabolic steroids and stimulant $[36,37]$.

In general, in 2013, the most requested substances belong to the class of diuretics and masking agents (29.3\%), anabolic agents (24.3\%) and stimulants $(21.2 \%)$.

In Table 3 are shown the data on the distribution of doping in the various Italian sports bodies. Before proceeding to the analysis, you must consider that data do not represent the degree of diffusion of doping within individual sports entities but should be understood only as the results obtained by Commission pursuant to the Italian Law $376 / 00$. In addition, other important circumstances to consider are that over time the various sports entities have changed their name and others were born over the past few years. From 2003 to 2012, the federation with a higher percentage of doped athletes is the FIGGMA Grappling Jiujitsu Martial Arts with 25\%, followed by FIB - Bowls with 18.2\%, FIBBN - Amateur Natural Bodybuilding with 13.2\% and $10 \%$ with FIDAF - American Football. The highest percentages - 50\% - are recorded in 2003, 2009 and 2010, respectively in FITRI -Thriathlon, FIH - Hockey and FIBS - Baseball and Softball.

\begin{tabular}{|c|c|c|c|c|c|c|c|c|c|c|c|}
\hline \multirow{2}{*}{$\begin{array}{l}\text { Sports Bodies } \\
\text { Years }\end{array}$} & \multicolumn{11}{|c|}{ 2003-2013 } \\
\hline & 3 & 4 & 5 & 6 & 7 & 8 & 9 & 10 & 11 & 12 & 13 \\
\hline CSAl - ACl - Car racing & 0 & 0 & & & 0 & & & & & & \\
\hline FASI - Climbing & 0 & 0 & 0 & 0 & 4.3 & & 0 & 0 & & 0 & 0 \\
\hline FCI - ACSI UDACE - UISP - Cycling & 6.1 & 6 & 2.8 & 2.4 & 4 & 12 & 4.4 & 9 & 4.5 & 4.3 & 6.5 \\
\hline Fcrl - Cricket & & 0 & & & & & & & & & \\
\hline FGI - gymnastics & 0 & 0 & 0 & 0 & 6.3 & 4.2 & & 0 & & 0 & 0 \\
\hline FIB - Bocce & & 16.7 & 25 & 16.7 & & & & & & & \\
\hline FIBa - Badminton & & 0 & 0 & & 0 & 0 & & & & & \\
\hline FIBBN - Amateur Bodybuilding Natural & & & & & 13 & 6.7 & 25 & 13 & 12.5 & & 17 \\
\hline FIBiS - Biliards & & 0 & 0 & & 0 & & & & & & \\
\hline FIBS - Baseball and Softball & 0 & 0 & 17 & 2.8 & 1.8 & 4.2 & 1.7 & 4.2 & 50 & 6.3 & 0 \\
\hline FIC - Rowing & 0 & 5 & 0 & 6.3 & 0 & 0 & 0 & 0 & & & 8.3 \\
\hline FICK - Canoe Kajak & 0 & 0 & 0 & 0 & 0 & 3.7 & 0 & 0 & 0 & 0 & 0 \\
\hline FICSF - canoe seat fixed & & 0 & 0 & 0 & 0 & & & & & & \\
\hline FIDAF - Amer. Football & & & & & & & & & & 13 & 8.3 \\
\hline FIDAL - track and field & 2.1 & 0 & 0 & 1.5 & 1.1 & 0 & 0.6 & 0.6 & 1.9 & 1.5 & 0 \\
\hline FIDS - Dance Sport & & & 2.5 & & 0 & & & & & & 0 \\
\hline FIG - Golf & & 0 & 25 & 9.1 & 3.2 & 0 & & & & 5.7 & 0 \\
\hline
\end{tabular}


Citation: Mazzeo F, Monda M, Messina G, Santamaria S, Messina A, et al. (2016) Doping in Italy: An Analysis of its Spread in Ten Years. Biol Med (Aligarh) 8: 263. doi:10.4172/0974-8369.1000263

Page 5 of 9

\begin{tabular}{|c|c|c|c|c|c|c|c|c|c|c|c|}
\hline FIGC - Football & 1 & 3 & 0.5 & 1.9 & 4.8 & 2.1 & 3.8 & 0 & 1.3 & 3.2 & 0.6 \\
\hline FIGeST - Games and Traditional Sports & 0 & & & & & & & & & & \\
\hline FIGH - Handball & 6.3 & 3.2 & 3.4 & 1.9 & 8.3 & 0 & 3.8 & 3.6 & 6.3 & 1.7 & 3 \\
\hline FIGMMA - Grappling Jiujitsu Martial Arts & & & & & & & & & & 25 & \\
\hline FIGS - Squash & 12.5 & 0 & 0 & 0 & & 0 & 5.6 & 0 & & & 0 \\
\hline FIH - Hockey & 6.3 & 0 & 0 & 0 & 3.1 & 0 & 0 & 50 & 12.5 & 4.2 & 0 \\
\hline FIHP - Hockey and Skating & 0 & & 0 & 6.1 & 0 & & 10 & & & & \\
\hline FIJLKAM - Judo Wrestilng Karate & 0 & 5.3 & 0 & 0 & 4.9 & & 0 & 0 & & 6.2 & \\
\hline FIKB - FIKBMS Kick Boxing & & & & & 0 & & & 6.7 & & 7.1 & 13 \\
\hline FIM - speedboat racing & & & & 8.3 & 0 & 0 & & & & & \\
\hline FIN -Swimming & 0 & 1.7 & 1.6 & 1.6 & 0 & 1.9 & 2.5 & 0 & 0.8 & 1.8 & 1.1 \\
\hline FIP - Basketball & 0 & 2.3 & 0.8 & 2.3 & 1.1 & 1.9 & 6.3 & 0 & 0 & 0.9 & 0 \\
\hline FIPAV - Volleyball & 0 & 0 & 1.5 & 2.5 & 1.1 & & 3.8 & 0 & 0.9 & 0 & 0 \\
\hline FIPE - FIPCF Weights and physical culture & 25 & 3.4 & 15 & 3.7 & & 4.2 & 0 & 11 & 9.7 & 0 & 13 \\
\hline FIPM -Modern Pentathlon & 0 & 0 & 0 & & & & & & & & \\
\hline FIPSAS - Game fishing & 0 & 0 & 0 & & 13 & & 13 & 0 & 0 & & 0 \\
\hline FIR -Rugby & 4.2 & 6.9 & 5.4 & 4.8 & 4.1 & & 3.1 & 5.3 & 5 & 9.2 & 5 \\
\hline FIS -Fencing & 0 & 6.3 & 4.3 & 3.6 & 0 & & 0 & & 0 & 0 & 0 \\
\hline FISB -Bowling & & 25 & & & 0 & & 0 & & & & 0 \\
\hline FISE - Equestrian sports & 6.3 & 0 & 0 & 5 & 0 & & & & & & 0 \\
\hline FISG - Ice Sports & 0 & 2.5 & 0 & 2.5 & 1.3 & 0 & 0 & 6.9 & 2.9 & 1.9 & 6.7 \\
\hline FISI - winter Sports & 0 & 1.9 & 2.9 & & 0 & 0 & 0 & 3.9 & 3.7 & 1.1 & 1.4 \\
\hline FISN - Water skiing & & 0 & & 0 & 0 & & & 0 & & & \\
\hline FIT -Tennis & 0 & 0 & 0 & 3.3 & 6.9 & 3.1 & 4.3 & 4.3 & 2.5 & 9.6 & 0 \\
\hline FITA - Taekwondo & & 6.3 & 0 & 0 & & 0 & 0 & & 0 & 0 & 0 \\
\hline FITARCO -Arkery & 10 & 0 & 4.5 & 6.3 & 4.2 & 0 & 6.2 & & 3.1 & 0 & 0 \\
\hline FITAV - Clay Pigeon Shooting & 12.5 & 0 & 6.7 & 0 & 0 & 0 & & & & 0 & \\
\hline FITeT - Table tennis & 0 & 0 & 0 & 0 & 0 & 0 & 0 & & 0 & & 0 \\
\hline FITRI -Triathlon & 50 & 0 & 0 & 9.1 & 1.5 & 0 & 5 & 1.5 & 0 & 5.7 & 0 \\
\hline FIV - Sailing & & & 8 & 0 & 5.6 & & & & & & 0 \\
\hline FIWuK - Wushu Kung Fu & & & 0 & & 0 & & & & & & \\
\hline FMI - Motorcycling & 0 & 8.3 & 8.3 & 0 & 6.3 & 8.3 & 0 & 25 & & & \\
\hline FPI -Boxing & 0 & 12.5 & 0 & 0 & 5 & 6.3 & 8.3 & 0 & & & 0 \\
\hline IBFF - Int. Bodybuilding & & & & & & & & & & 0 & \\
\hline UITS - shooting gallery & 0 & 5.3 & & 0 & 14 & 0 & & & & & \\
\hline
\end{tabular}

Table 3: Percentages of doped athletes. Breakdown by sports bodies. Reference period: 2003 - 2013. From: Ministero della Salute, 2013. 


\section{Discussion}

It is important to ask why athletes dope. One thing is certain the substances that give pleasant sensations or help the subject in his activity will bring him to repeat the consumption. But not all people develop drug dependence. It depends on several factors: the socioenvironmental context of the subject and what effects have the substance in the body. Moreover the drug dependence could be connected to the indirect gratification. It consists in all situations in which the person has a social, economical or psychological benefit thanks to use drugs. For example: we can see direct gratification in the winning of a competition and indirect gratification in the money that the athlete receives after. If all the gratifications are connected to use of drug, maybe he will use drug in the future.

Lots of researches focused their attention on subject's personality distinguishing, in particular, people with an ego and a task orientation. Those researches demonstrate how one kind of that orientation is linked to drug dependence $[34,38,39]$.

People with an ego orientation have a low self-esteem. They are aware that only with their own abilities fail in their main purpose: to beat the others. They also hate the defeat and, therefore, looking for the victory in any way.

People task oriented have a good self-esteem. They believe that only with diligence and with its own forces can overcome obstacles and achieve results. Their goal is not to deal with others only to appear but to put into practice the results of their efforts. The defeat is not seen as a personal failure but as a message to do more.

Perhaps, an ego oriented person probably will use drugs because he doesn't want to improve himself but only give the appearance of improvement; and this result will get it only through the use of performance-enhancing drugs [40-42].

Kahneman and Tversky give us others reasons that push people to resort to doping [43-45]. Indeed, they identify four factors: the effect of formulation, the principle of utility, the heuristic of the accessibility and the representativeness heuristic.

The first factor - the effect of formulation - consists in the way in which the message is transmitted. With this effect, there is an alteration in communication between advantage and disadvantage. Applied to doping, it means that the athlete will underline the enormous benefits arising from the use of performance-enhancing drugs compared to low risk.

With the second factor - principle of utility - the athlete focuses his attention only on the advantages linked to the use of abovementioned drugs and he doesn't prefer thinking to negative consequences.

The heuristic of accessibility teach us that if an athlete does not think of negative consequences, it is due to ignorance about them. Indeed, he tends to overlook the possibility that an event occurs because, for example, he has never seen before the above-mentioned consequences. Finally, with the last one heuristic, we understand that the only aim of an athlete is to become like his idol, at any cost $[46,47]$.

Considering some of above reported substances, we can underline the various gratifications' effects.

Stimulants are used to increase the concentration, alertness and safety. They also increase the aggressiveness and the sense of competitiveness.
To anabolic are recognized for the following effects: euphoria, sense of wellbeing, glee, increased motivation and self-esteem. Moreover, the athlete doesn't get bored during the training.

Narcotics have a calming effect on the psyche as well as betablockers reduce the anxiety and stress. Corticosteroids have, instead, a stimulating effect like alcohol. Moreover, other effects include: euphoria, increased sociability and sense of wellbeing.

Cannabinoids, such as cannabis, hashish and marijuana, cause changes in mood and perception, euphoria, happiness, relaxation and deep sleep and reducing anxiety. They are considered drug to use social-recreational $[16,48]$.

\section{Preventive measures to adopt}

The first step to prevent the recourse to the doping is to extend the knowledge on it and in particular on its dangerous effects on health [37,49]. Indeed, most athletes will not have enough knowledge to fully understand the potential health hazards caused by it. It is necessary, therefore, that public and sports institutions implement information and awareness campaigns aimed particularly to younger. This can be achieved only with strict collaboration between the two abovementioned institutions. It's necessary to enhance the role of local institutions and the National Olympic Committee to give tools, especially economic, to carry out the work of education, training and control [50].

It is important that campaigns are launched to a broad audience too. These awareness-promoting actions must involve mass media [50].

In terms of training, expressly the doctors who are at the forefront and unfortunately, often have a very sketchy understanding of the relationship between therapy and doping, particularly in terms of knowing which treatments are permitted and which are not $[50,51]$.

From a scientific point of view, one of the most effective preventive measures could be the inclusion in the class S0 - substances not approved - of doping substances of Law 376/2000, also drug for veterinary purposes in view of the spread of this type of medication for doping [36].

Another preventive measure to curb the problem is the liberalization of doping. The basic thesis of this "risky" proposal is to minimise the damage. The basic idea is that the current system of restrictions has not been able to vanquish the problem [52]. Athletes dope in unsafe structures with an exponential increase in the risks for the health. The solution of liberalization allows athlete to go in appropriate health facilities and not clandestine. Moreover, now, because of secrecy in which doping moves, it is impossible to estimate the spread of his usage. Thus, with the liberalization, you could understand the effective dissemination and the damage that it has caused to the doped athletes. Furthermore, with the complete data you could adopt adequate measures [53].

\section{Preventive measures adopted}

WADA, in 2004, drew up a Code that is constantly emended. The Code explains not only "what is" doping but it contains sanctions too.

Others instruments used to contrast doping are the accredited laboratories, the Biological Passport and the ADAMS [54].

The laboratories have an important role in the discovery of new substances; most of them are included in the WADA List. They also 
determine the quantitative of those substances, carry out anti-doping tests, determine cases, criteria and methodologies of anti-doping tests too. Currently, there are 32 laboratories in the World [30].

The Biological Passport is a tool for indirect detection of the presence of a doping substance in biological samples of an athlete. With it, in fact, the changes of certain bio-markers of doping are recorded and monitored. If the data, combined with the personal data localization in a given period, exceeded a certain range, the athlete would assume the banned substances [35].

The Anti-Doping Administration and Management System (ADAMS) is an on-line database system where are recorded all data: laboratory results, therapeutic use exemptions (TUEs) and information on anti-doping rule violations. It allows the sharing of information amongst the organizations and promotes efficiency, transparency and effectiveness in all anti-doping activities.

Furthermore, three projects were funded in 2012 in Italy. The first project, National System Alert Doping, is aimed at the early identification of new substances and methods used for the purpose of doping and thus the activation of reports warning of all relevant agencies. The second one, Identification of new potential doping agents and/or masking and related analytical markers, in collaboration with the laboratory of "Acqua Acetosa" in Rome, is aimed to development of new technologies for the detection of new markers. The last one, Prevalence of the use of anabolic steroids and stimulants assessed by hair analysis in the population of youth and amateur sports, promotes healthy lifestyles through the estimate of the prevalence of anabolic steroids and stimulants [10].

Moreover, in 1998 the European Commission funded a project known as "Hardop", Harmonisation of Methods and Measurements in the Fight against doping, with the aim to identify the research necessary to improve the way in which doping in sport can be combated. The project's final report, published in 1999, underlined the need for new developments not only in measurement and testing technologies but also in coordination and education. Indeed, the Commission has funded a number of projects with the aim to improve the ability to detect the use of drugs. However, the development of synthetic steroids with the same chemical structure as naturally occurring steroids has made their detection much more difficult. One of the funded projects, Isotrace, had the aim to develop the new Isotope Ratio Mass Spectrometry (IRMS) technology to detect the specific isotope content of prohibited synthetic hormones. With the project identified as SGLC/MS, there have been developed mainly new Liquid Chromatography/Mass Spectrometry (LC/MS) techniques for rapid detection of Anabolic Androgenic Steroids (AAS). Lastly, with Aladin 2002, the EU has developed a proficiency-testing programme for implementation among European IOC accredited laboratories. Following ISO/IEC guidelines, it was established to set up and accredit a network of centres as qualified suppliers of the proficiency-testing schemes with a computer-based network connecting the European IOC-accredited laboratories to guarantee adequate, fast, consistent and confidential distribution of information necessary for the inter-lab testing programme. This network is open to non-European laboratories $[55,56]$.

\section{Conclusion}

When we talk about doping, in particular of statistics and percentages, we just touch "the tip of the iceberg" [57] In fact, the secrecy that characterizes the doping hinders the implementation of epidemiological investigations. On closer inspection, if the data collected through the tests correspond to reality, there isn't a real emergency [22,58-60]. In addition, the anti-doping tests provide insufficient data for statistical extrapolations and accurate estimates of the phenomenon, because of the small number of athletes tested and the imprecision of the methods of research. The lack of statistical significance is precisely due to the low sampling of the tests, compared to tens of millions of athletes engaged in sports practices also outside of the vertices competitive $[56,61,62]$.

At the present, the tests are based on urine samples. Blood tests should enable verification of the level of haematocrit or haemoglobin. This type of analyses based on more specific parameters (direct or indirect) could well reveal forms of doping that cannot be detected in urine [50,63-65].

To confirm what said up to now, in April 2006, DOXA Institute submitted 508 athletes to an anonymous questionnaire about beliefs on and attitude on doping of Italian athletes. They "confessed" that the tests are infrequently and poorly effective and they should be more frequent and follow a different protocol $[66,67]$.

The current system of the fight against doping makes the assessment carried out by analytical laboratories accredited by WADA as a test not able to analyse the state of health of the athlete but as a real anti-fraud control: the goals are diametrically opposed (Table 4) [36,68].

\begin{tabular}{|c|c|c|}
\hline & $\begin{array}{l}\text { Chemical-clinical } \\
\text { analysis }\end{array}$ & Antidoping tests \\
\hline Matrix & The most suitable one & $\begin{array}{l}\text { mainly urine blood only in } \\
\text { special cases }\end{array}$ \\
\hline \multirow{4}{*}{ Finality } & diagnostic tests & to supply evidence \\
\hline & $\begin{array}{l}\text { Certificate of analysis } \\
\text { based on: }\end{array}$ & Test report based on: \\
\hline & $\begin{array}{l}\text { 1) identification and } \\
\text { quantification of specific } \\
\text { markers; }\end{array}$ & $\begin{array}{l}\text { 1) identification of specific } \\
\text { substances (drugs } \\
\text { metabolites); }\end{array}$ \\
\hline & $\begin{array}{l}\text { 2) multiparameter } \\
\text { profiles. If doubt = } \\
\text { positive then they have } \\
\text { to follow further } \\
\text { investigations }\end{array}$ & $\begin{array}{l}\text { 2) longitudinal assessments. } \\
\text { If doubt = negative then you } \\
\text { do not have to follow further } \\
\text { investigations }\end{array}$ \\
\hline
\end{tabular}

Table 4: Differences between chemical-clinical analysis and ant doping tests.

Unfortunately, today, despite the technological advancement that characterizes the field of scientific research, the analytical methods are not sufficiently reliable for the search of the entire group of substances included in the anti-doping lists. Even in the case in which the substances are identified, there are cases of dispute and the few economic resources are used for further study on the same samples to athletes rather than new research. In addition, it is impossible to anticipate the moves of the opponent and this, therefore, is not easy to understand what new substances will be taken and what new methods will be adopted $[36,69,70]$.

According to art. 4 of the Law 376/2000, one or more laboratories accredited by the IOC or by another international organization analyse the samples of controlled athletes. The reason of this choice is to guarantee the reliability and impartiality of the controls. After the establishment of WADA, this entity was incorporated into the system 
of accreditation. This is to ensure maximum harmonization of techniques and methods of analysis followed by those laboratories. In Italy, there is only one accredited laboratory, in Rome: the Anti-doping Laboratory of "Acquacetosa".

Close collaboration among the laboratories themselves would enable them to keep up to date and exchange new techniques. Closer ties with the pharmaceutical industry and those involved in basic research are also vital if they are able to anticipate new tendencies and forms of doping by means of a sort of scientific "vigil". The instrumentation and measurements industry would be also able to give them the benefit of recent progress in their domain [50]

\section{Perspectives}

The results of this research carried out in Italy can be considered as a reference for other countries, especially those in which the doping is more frequent and actions to combat doping itself less effective. In view of the serious damage to health, all countries should encourage long-term clinical studies about the harmful effects caused by doping. In addition, more effective laws to combat the use of performanceenhancing drugs should be taken. Finally, programs of health education to prevent the use of substances, improperly used to improve sports performance, should be encouraged with specific funding.

\section{References}

1. Santamaria S, Ascione A, Domenico T, Mazzeo F (2013) Gene Doping: biomedical and law aspect of genetic modification of athletes. Med Sport 17: 193-199.

2. Sjoqvist F, Garle M, Rane A (2008) Use of doping agents, particularly anabolic steroids, in sports and society. Lancet 371: 1872-1882.

3. Agullo-Calatayud V, González-Alcaide G, Valderrama-Zurián JC Aleixandre-Benavent R (2008) Consumption of anabolic steroids in sport, physical activity and as a drug of abuse: an analysis of the scientific literature and areas of research. Br J Sports Med 42: 103-9.

4. Valenzano A, Moscatelli F, Triggiani AI, Capranica L, De Ioannon G, et al. (2015) Heart Rate Changes After Ultra-Endurance Swim From Italy to Albania: A Case Report. Int J Sports Physiol Perform. Aug 10 [Epub ahead of print].

5. Dilger A, Frick B, Tolsdorf F (2007) Are athletes doped? Some theoretical arguments and empirical evidence. Contemp Econ Policy 25: 604-615.

6. Messina G, Vicidomini C, Viggiano A, Tafuri D, Cozza V, et al. (2012) Enhanced parasympathetic activity of sportive women is paradoxically associated to enhanced resting energy expenditure. Auton Neurosci Basic Clin 169: 102-106.

7. Esseiva P, Ioset S, Anglada F, Gasté L, Ribaux O, et al. (2007) Forensic drug intelligence: an important tool in law enforcement. Forensic Sci Int 167: 247-254.

8. Viggiano A, Vicidomini C, Monda M, Carleo D, Carleo R et al. (2009) Fast and low-cost analysis of heart rate variability reveals vegetative alterations in noncomplicated diabetic patients. J Diabetes Complications 23: 119-123.

9. Monda M, Messina G, Scognamiglio I, Lombardi A, Martin GA, et al. (2014) Short-Term Diet and Moderate Exercise in Young Overweigh Men Modulate Cardiocyte and Hepatocarcinoma Survival by Oxidative Stress. Oxid Med Cell Longev 2014: 1-7.

10. Møller V, Dimeo P (2014) Anti-doping - the end of sport. Int J Sport Policy Polit 6: 259-272.

11. Messina G, Palmieri F, Monda V, Messina A, Dalia C et al. (2015) Exercise Causes Muscle GLUT4 Translocation in an Insulin-Independent Manner. Biol Med (Aligarh) S3: 007.
12. Di Bernardo G, Messina G, Capasso S, Del Gaudio S, Cipollaro M, et al. (2014) Sera of overweight people promote in vitro adipocyte differentiation of bone marrow stromal cells. Stem Cell Res Ther 5: 4.

13. Marclay F, Mangin P, Margot P, Saugy M (2013) Perspectives for Forensic Intelligence in anti-doping: thinking outside of the box. Forensic Sci Int 229: 133-144.

14. De Luca V, Viggiano E, Messina G, Viggiano A, Borlido C, et al. (2008) Peripheral amino Acid levels in schizophrenia and antipsychotic treatment. Psychiatry Investig 5: 203-208.

15. Mazzeo F, Motti ML, Messina G, Monda V, Ascione A, Tafuri D, Palmieri F, Messina A, Monda M (2013) Use of nutritional supplements among south Italian students of physical training and sport university. Curr Top Toxicol 9: 21-26.

16. Rattei T, Tischler P, Arnold R, Hamberger F, Krebs J, et al. (2008) SIMAP--structuring the network of protein similarities. Nucleic Acids Res 36: D289-292.

17. Rinaldi B, Guida F, Furiano A, Donniacuo M, Luongo L, et al. (2015) Effect of Prolonged Moderate Exercise on the Changes of Nonneuronal Cells in Early Myocardial Infarction. Neural Plast 2015: 265967.

18. Esposito M, Serpe FP, Diletti G, Messina G, Scortichini G, et al. (2014) Serum levels of polychlorinated dibenzo-p-dioxins, polychlorinated dibenzofurans and polychlorinated biphenyls in a population living in the Naples area, southern Italy. Chemosphere 94: 62-69.

19. Lippi G, Banfi G, Franchini M, Guidi GC (2008) New strategies for doping control. J Sports Sci 26: 441-445.

20. Kamber M (1990) The fight against doping: international and national efforts as exemplified by the Convention of the Council of Europe and the doping regulations of the Swiss National Association for Sports. Schweiz Z Sportmed 38: 101-6.

21. Triggiani A, Valenzano A, Ciliberti MA, Moscatelli F, et al. (2015) Heart rate variability is reduced in underweight and overweight healthy adult women. Clin Physiol Funct Imaging .

22. Presidenza del Consiglio dei Ministri - National Bioethics Committee. Ethics, Sport and Doping. 2010.

23. Monda M, Messina G, Mangoni C, De Luca B (2008) Resting energy expenditure and fat-free mass do not decline during aging in severely obese women. Clin Nutr 27: 657-659.

24. Messina G, De Luca V, Viggiano ADT, Messina A, Moscatelli F, et al. (2015) Activity of Autonomic Nervous System, Energy Expenditure and Assessment of Oxidative Stress in Menopause-women Using Hormone Replacement Therapy. Br J Med Med Res 10: 1-13.

25. Botrè F (2008) New and old challenges of sports drug testing. J Mass Spectrom 43: 903-907.

26. Messina G, De Luca V, Viggiano A, Ascione A, Iannaccone T, et al. (2013) Autonomic nervous system in the control of energy balance and body weight: personal contributions. Neurol Res Int 2013: 639280.

27. Messina G, Viggiano A, Tafuri D, Palmieri F, De Blasio S, et al. (2014) Role of orexin in obese patients in the intensive care unit. J Anesth Clin Res 5: 395.

28. Messina G, Viggiano A, De Luca V, Messina A, Chieffi S, et al. (2013) Hormonal changes in menopause and orexin-a action. Obstet Gynecol Int 2013: 209812.

29. Dvorak J, Baume N, Botré F, Broséus J, Budgett R, et al. (2014) Time for change: a roadmap to guide the implementation of the World AntiDoping Code 2015. Br J Sports Med 48: 801-6.

30. Valkenburg D, de Hon O, van Hilvoorde I (2014) Doping control, providing whereabouts and the importance of privacy for elite athletes. Int J Drug Policy 25: 212-218.

31. Strano Rossi S, Botrè F (2011) Prevalence of illicit drug use among the Italian athlete population with special attention on drugs of abuse: a 10year review. J Sports Sci 29: 471-476.

32. Badoud F, Guillarme D, Boccard J, Grata E, Saugy M, et al. (2011) Analytical aspects in doping control: challenges and perspectives. Forensic Sci Int 213: 49-61. 
33. Moscatelli F, Messina G, Valenzano A, Petito A, Triggiani AI, et al. (2015) Relationship between RPE and Blood Lactate after Fatiguing Handgrip Exercise in Taekwondo and Sedentary Subjects. Biol Med (Aligarh) S3: 008.

34. Messina G, Zannella C, Monda V, Dato A, Liccardo D, et al. (2015) The Beneficial Effects of Coffee in Human Nutrition. Biol Med (Aligarh) 7: 240.

35. WADA (2015) World Anti-Doping Code. World Anti-Doping.

36. Ministero della Salute (2013) Reporting System Doping Antidoping.

37. Giovanni M, Monda V, Moscatelli F, Valenzano AA, Monda G, et al. (2015) Role of Orexin System in Obesity. Biol Med (Aligarh) 7: 248.

38. Serpelloni G, Bertoncelli S, Zermiani M. Dipendenza da sostanze dopanti e dipendenza da sostanze stupefacenti: un modello interpretativo [Dependence on performance-enhancing drugs and drug dependence: an interpretative model] Chap. 1. In Doping. Aspe.

39. Messina G, Dalia C, Tafuri D, Monda V, Palmieri F, et al. (2014) Orexin-A controls sympathetic activity and eating behavior. Front Psychol 5: 997.

40. Duda JL, Nicholls JG (1992) Dimensions of achievement motivation in schoolwork and sport. J Educ Psychol 84: 290-299.

41. Duda JL, Chi L, Newton ML, Walling MD (1995) Task and ego orientation and intrinsic motivation in sport. Int J Sport Psychol 26: 4063.

42. Viggiano A, Chieffi S, Tafuri D, Messina G, Monda M, et al. (2014) Laterality of a second player position affects lateral deviation of basketball shooting. J Sports Sci 32: 46-52.

43. Tversky A, Kahneman D (1974) Judgment under Uncertainty: Heuristics and Biases. Science 185: 1124-1131.

44. Kahneman D, Tversky A (1979) Prospect Theory: An Analysis of Decision under Risk. Econometrica 47: 263-292.

45. Chieffi S, Iachini T, Iavarone A, Messina G, Viggiano A, et al. (2014) Flanker interference effects in a line bisection task. Exp Brain Res 232: 1327-1334.

46. Santamaria S, Mazzeo F (2014) Ethical issues and doping in Olimpic and Paralympic Games. Med Sport 10: 2411-2417.

47. Chieffi S, Iavarone A, Iaccarino L, La Marra M, Messina G, et al. (2014) Age-related differences in distractor interference on line bisection. Exp Brain Res 232: 3659-3664

48. Chieffi S, Iavarone A, La Marra M, Messina G, Dalia C, et al. (2015) Vulnerability to Distraction in Schizophrenia. J Psychiatry 171: 1-7.

49. Thomas JO, Dunn M, Swift W, Burns L (2011) Illicit drug knowledge and information-seeking behaviours among elite athletes. J Sci Med Sport 14 278-282.

50. de Me'rode A, Schamasch P (1999) Harmonisation of methods and measures in the fight against doping in sport. Final report. European Commission. Directorate General for Research, Luxembourg: Office for Official Publications of the European Communities.

51. Messina G, Chieffi S, Viggiano A, Tafuri D, Gibelli G, et al. (2015) Parachute Jumping Induces More Sympathetic Activation Than Cortisol Secretion In First-Time Parachutists. Asian J Sport Med 6: 1-7.

52. Pour HRS, Rahnama N, Bambaeichi E, Naderian M, Hosseini MS, et al. (2010) Statistics Related to doping and Type of Doping Drugs in Universal Sport. World J Sport Sci 2: 184-189.

53. Kayser B, Mauron A, Miah A (2005) Viewpoint: Legalisation of performance-enhancing drugs. Lancet 366 Suppl 1: S21.

54. Overbye M, Knudsen ML, Pfister G (2013) To dope or not to dope: Elite athletes' perceptions of doping deterrents and incentives. Perform Enhanc Heal 2: 119-134.
55. Sgalambo E, Toninel C. Il ruolo delle istituzioni sportive nella lotta al doping [The role of sports institutions in the fight against doping]. Doping. Aspetti medici, Nutr. Psicopedag. Leg. ed etici e indicazioni per la prevenzione, [Doping. Medical, Nutr. Psychol. methods, Leg. ethical issues Dir. Prev]

56. Monda M, Viggiano A, Viggiano A, Mondola R, Viggiano E, et al. (2008) Olanzapine blocks the sympathetic and hyperthermic reactions due to cerebral injection of orexin A. Peptides 29: 120-126.

57. Striegel H, Ulrich R, Simon P (2010) Randomized response estimates for doping and illicit drug use in elite athletes. Drug Alcohol Depend 106: 230-232.

58. Esposito T, Viggiano A, Viggiano A, Viggiano E, Giovane A, et al. (2006) ICV injection of orexin A induces synthesis of total RNA and mRNA encoding preorexin in various cerebral regions of the rat. J Therm Biol 31: 527-532.

59. Mondola P, Ruggiero G, Serù R, Damiano S, Grimaldi S, et al. (2003) The $\mathrm{Cu}, \mathrm{Zn}$ superoxide dismutase in neuroblastoma SK-N-BE cells is exported by a microvesicles dependent pathway. Brain Res Mol Brain Res 110: 45-51.

60. Viggiano A, Viggiano A, Monda M, Turco I, Incarnato L, et al. (2006) Annurca apple-rich diet restores long-term potentiation and induces behavioral modifications in aged rats. Exp Neurol 199: 354-361.

61. Ferrara SD (2004) Doping Antidoping. Piccin Nuova Libraria SpA Padova.

62. Monda M, Amaro S, De Luca B (1994) Non-shivering thermogenesis during prostaglandin E1 fever in rats: role of the cerebral cortex. Brain Res 651: 148-154.

63. Monda M, Viggiano A, Viggiano A, Fuccio F, De Luca V (2004) Clozapine blocks sympathetic and thermogenic reactions induced by orexin $\mathrm{A}$ in rat. Physiol Res 53: 507-513.

64. Monda M, Amaro S, De Luca B (1993) The influence of exercise on energy balance changes induced by ventromedial hypothalamic lesion in the rat. Physiol Behav 54: 1057-1061.

65. Monda M, Viggiano A, Viggiano A, Fuccio F, De Luca V (2004) Injection of orexin A into the diagonal band of Broca induces sympathetic and hyperthermic reactions. Brain Res 1018: 265-271.

66. Tavani A, Colombo P, Scarpino V, Zuccaro P, Pacifici R, Vecchia C La (2012) Beliefs on and Attitude toward Doping Use Among Athletes: an Italian Survey. Ital J Public Health 9: 1-7.

67. Giovanni Messinaa, Anna AValenzano, Fiorenzo Moscatelli, Antonio I Triggiani, Laura Capranica, et al. (2015) Effects of Emotional Stress on Neuroendocrine and Autonomic Functions in Skydiving. J Psychiatry 18: $1-7$.

68. Colucci AP, Gagliano-Candela R (2004) Validity of the analytical data of the chemical-clinical and toxicological laboratory. Bollettino per le Farmacodipendenze e l'Alcolismo 27: 37-46.

69. Monda M, Messina G, Vicidomini C, Viggiano A, Mangoni C, et al. (2006) Activity of autonomic nervous system is related to body weight in pre-menopausal, but not in post-menopausal women. Nutr Neurosci 9: 141-145

70. Monda M, Viggiano A, Viggiano A, Viggiano E, Messina G, et al. (2007) Sympathetic and hyperthermic reactions by orexin A: role of cerebral catecholaminergic neurons. Regul Pept 139: 39-44. 